\title{
ODONTOLOGÍA Y COVID-19
}

Se ha creado por la cuarentena, una especie de incertidumbre en los pacientes, en los profesionales, en las familias, en la sociedad en general.

Analizando la situación, de la Odontología, no solo vive el profesional, sino también toda su familia, el laboratorista y su familia, las asistentes dentales, la secretaria, la empresa de residuos patológicos. Esto se traduce hablando en términos económicos, en crisis. Las cuentas tarde o temprano hay que pagarlas.

El temor al contagio por parte de los colegas y por parte de los pacientes, también hace crítica la situación. El tema pasa porque no todos los que hablan u opinan, lo hacen con el suficiente respaldo científico, no se puede opinar de algo tan delicado, solamente leyendo los diarios, o mirando la televisión. Las redes sociales, muchas veces confunden, las noticias, también. Hay personas muy sensibles a quienes esta crisis afecta y mucho y esto va más allá de si son profesionales de la medicina o no. Para eso están los psicólogos y los psiquiatras, pero también tenemos: infectólogos, epidemiólogos, estadistologos, virologos, microbiólogos, que opinan desde sus puntos de vista. Todo es respetable.

Como si eso fuera poco, aparecen en nuestro camino, los políticos, que deben tomar decisiones de todo tipo y color y que no siempre son correctas.

Entonces digo: ¡iii qué difícil tener el título de Odontólogo en estos momentos !!!!. Los lugares convencionales de formación profesional, disminuidos. Prestigiosas Instituciones odontológicas de nuestro país, impedidas de abrir sus puertas para formación profesional, únicamente en forma virtual, con las limitaciones claras del caso. Colegas docentes, imposibilitados de ejercer lo que más quieren: la docencia. Profesionales jóvenes impedidos de formarse.

Entonces la pregunta es: ¿Qué hacer?

Como profesional, como ser humano, como ciudadano, como padre o madre de familia, la vida continúa y los temores existen. El riesgo de contagio de las personas, comienza cuando salen de su hábitat normal, y si voy al Odontólogo, ¿aumenta ese riesgo? indudablemente: sí, porque salimos de casa ¿y si atiendo?, la respuesta es afirmativa.

Pero ojo, que existen recaudos a tomar de las partes que hacen disminuir ese riesgo. Todos los conocemos.

Si fumo 3 atados de cigarrillos por día, ¿tengo riesgo de cáncer de pulmón? si, mucho y si no fumo, tambien, pero menos.

Debemos "vivir" la vida, no sufrirla. Aprendamos a convivir con un virus que nos ha tocado en suerte en esta época, pero también es real que convivimos con la posibilidad de tuberculosis, de enfermedades cardiacas, vasculares, hepáticas, renales, sanguíneas, neurológicas.

Si trabajamos con alegría y esperanza, seguro que lograremos mejores resultados, pero si estamos convencidos que lo mejor es: no atender, no lo hagamos, pero por Dios que lo que hagamos sea con convicción. Esa es la mejor forma de atravesar esta crisis. 